\title{
Velázquez Castro, M. (2020). Hijos de la peste. Una historia de las epidemias en el Perú. Lima: Taurus.
}

Como dijo Hegel: "el búho de Minerva solo levanta vuelo en el crepúsculo". Con esta poética frase, el filósofo alemán quiso decir que el conocimiento solo puede lograrse cuando el evento estudiado ha concluido. Por eso, el desfase cronológico entre el fenómeno estudiado y el análisis de este suele ser una de las características de la investigación académica. Sin embargo, este no es del todo el caso de Hijos de la peste. Una historia de las epidemias en el Perú, el reciente libro de Marcel Velázquez Castro. No solo es el tema de las epidemias relevante al presente en que vivimos, sino que el libro responde a la emergencia sanitaria causada por la COVID-19 y, además, increíblemente, ha sido escrito durante la actual pandemia. Pero más allá de esta sorprendente actualidad, este es un libro que combina con inteligencia y pasión el estudio histórico, el comentario social, la crítica literaria y cultural, y el lúcido análisis del presente. Hijos de la peste es, entre muchas cosas, una muestra de lo fructífero que puede ser el encuentro entre la historia y los estudios culturales.

Caracterizado por el manejo ejemplar de las fuentes históricas, incluye lúcidas lecturas de textos literarios; tanto nacionales, por ejemplo, La ciudad de los tísicos, de Abraham Valdelomar y "La muerte de los Arangos", de José María Arguedas, llamado por Velázquez, "el novelista más significativo del siglo XX peruano"; como internacionales, entre estas, Muerte en Venecia de Thomas Mann, Los novios de Alessandro Manzoni y varios cuentos de Edgar Allan Poe. También incluye fascinantes análisis de imágenes: de archivos periodísticos, de arte, de La nueva corónica de Guamán Poma y, en particular, las caricaturas de revistas satíricas, como Fray K.Bezón y Monos y Monadas. Además, estudia la publicidad de medicinas y productos de belleza que sirven para reconstruir el mundo intelectual e ideológico estudiado. Compuesto, además de una introducción y un epílogo, por cuatro secciones - "Historia", "Miedo", "Violencia", y "Humor"-, Hijos de la peste utiliza estos temas como lentes a través de los cuales busca entender el impacto de las epidemias en el Perú desde el incario, ya que, como afirma el autor, la viruela jugó un papel central en la conquista del Tahuantisuyo, hasta el presente.

En la "Introducción", Velázquez describe la situación personal y social desde la cual escribió el libro, y desde la cual muchos lo leemos: "Refugiados en nuestras propias casas, arrojados a un insólito tiempo propio, agobiados por la incertidumbre, los que amamos la historia y la literatura nos sentimos más inútiles que nunca. Sin embargo, ese desasosiego invita al impulso agónico del ensayo para sembrar aporías, reflexionar desde la cultura y cuestionar el camino trazado por la necesidad y la utilidad". Además de evidenciar la elegancia y precisión que caracterizan la escritura del libro, y que hacen que su lectura sea un placer, este breve pasaje muestra la manera en que Hijos de la peste estudia al pasado desde las preocupaciones del pre- sente, aunque, cabe señalar, sin por eso, distorsionar el análisis histórico. De hecho, el autor establece no solo una historia de las epidemias, situándolas en el contexto de la desigualdad económica, racial y cultural que ha caracterizado al Perú desde la colonia, sino que plantea inclusive lo que Foucault llamaba una genealogía de los discursos y del poder ligados a las epidemias y a las respuestas sociales ante estas. Como se señala en la "Introducción", "Una epidemia es siempre una máquina de construir desigualdades, espacios degradados, como las fosas comunes y los cementerios clandestinos, e ilusiones peligrosas como las teorías conspirativas y los remedios 'mágicos' de ayer y de hoy". Sin embargo, el libro no solo enfatiza la continuidad entre el pasado y el presente, sino que es consciente de los cambios en la historia, sobre todo el surgimiento de actitudes científicas hacia la enfermedad. De hecho, Velásquez señala: "Creo en la ciencia, no en rezos y ayunos; respeto el trabajo en condiciones terribles que vienen realizando los trabajadores de la salud en todas las grandes ciudades del mundo, pero no quiero un futuro en el que se limiten médicamente las interacciones entre los cuerpos, y el deseo se administre con recetas".

La sección "Historia" está dividida en cuatro apartados: "El incendio, la quimera y la política", "El largo grito del encuentro", "La ilustración y sus enfermedades" y "Las ratas de la modernidad". Así, empieza analizando la destrucción del Lazareto de las Maravillas en 1909, ordenado por el entonces alcalde Guillermo Billinghurst. Originalmente un espacio en el cual se aislaba a los enfermos de lepra, la enfermedad más temida durante la antigüedad y el medioevo; "aunque el célebre Lázaro no murió de esa enfermedad", el lazareto se convirtió en el lugar en el cual se aislaban a los individuos enfermos que llegaban a Lima. Para Velásquez, el incendio del lazareto marca un parteaguas en la actitud hacia las epidemias, ya que "condensa las tensiones entre el moderno mandato autoritario higienista y las instituciones tradicionales de tratamiento de las epidemias".

De esta manera empiezan a imponerse los métodos de la ciencia moderna sobre los métodos curativos tradicionales, heredados de la colonia, en última instancia, de la España medieval, y ligados a la Iglesia católica. El nuevo Lazareto de Guía, construido siguiendo las nuevas normas sanitarias, respondió a un brote de la peste bubónica: "Estuvo bajo la férula de la Dirección de Salubridad y atendió también a enfermos de lepra y viruela". Pero lo importante de este giro en cuanto al manejo de la salud pública radica en que responde a una creciente consciencia, sobre todo en los grupos políticos y en la opinión pública ilustrada, del papel central de los "novedosos microorganismos 'microbios'". Sin embargo, cabe recordar que "ya desde 1880 habían sido descubiertos como causantes de enfermedades infecciosas en Europa y acá también entre los médicos se había divulgado su papel en las epidemias". De hecho, "Histo- 
ria" narra la progresiva diseminación entre las élites culturales y económicas de las ideas modernas sobre las enfermedades. Sin embargo, y aunque suene paradójico, además de un creciente conocimiento médico, "[a] mayor desarrollo de una sociedad, obviamente, mayor concentración de población en un espacio urbano y alta interacción (muchas veces, destructiva) con animales con fines de domesticación, alimentación y comercio". $Y$ este desequilibrio poblacional y ecológico promueve el surgimiento de nuevas epidemias.

"Miedo" está compuesto por seis capítulos: "La carroza y las cenizas", "El vuelo de la Virgen", "Apocalipsis y consumo", "La profecía y La Niña", "El hospital y la estadística", y "Los piojos y la mosca azul". Como su nombre indica, el énfasis es puesto en las reacciones de la población ante las epidemias $y$, otra vez, el punto de partida es el inicio del siglo XX. En este caso, es en 1904, cuando, como parte del intento de aplicar las nuevas ideas sanitarias, el municipio empezó a utilizar un "carruaje gris, con una sola entrada en la parte posterior" para trasladar a los enfermos al nuevo lazareto. "Forrado de zinc", aparentemente para evitar contagios, fue conocida popularmente como "La carroza". De esta manera, la población limeña hizo eco de la iconografía europea ya que "[e]n el imaginario europeo de la peste, la muerte que atraviesa implacable las ciudades cada cierto tiempo se materializa, entre otras figuraciones, en la carreta con cadáveres, conducida por un esqueleto". El temor generado por las pandemias explica que "el cochero Maldonado sea indígena", ya que "su oficio se asocia con una labor infame... una tarea para los otros de una cultura" y el que hoy "muchos de los trabajadores que cargan los cadáveres de los muertos por la COVID-19 en los cerros de Lima [sean] inmigrantes venezolanos". Este miedo también explica la búsqueda de ayuda divina desde los sacrificios humanos andinos hasta el vuelo de la Virgen de Chapi en helicóptero el 10 de mayo de 2020, cortesía de la minera Cerro Verde, y con el beneplácito del arzobispo de Arequipa, para compensar la imposibilidad de las masas al santuario de Polobaya.

"Violencia", la tercera sección, está compuesta por los capítulos "El cólera y los jóvenes", "Epidemias y racismo", "Los ojos del Estado: control, resistencia y estigma", y "Espacios degradados e ilusiones peligrosas". Dado los títulos de los capítulos, y su énfasis en el papel represivo del Estado, no debe sorprender que esta sección empiece con un epígrafe tomado de Vigilar y castigar de Foucault. De hecho, la sección enfatiza la manera en que las epidemias han servido a lo largo de la historia peruana para reprimir a grupos sociales y raciales, al usarlos como chivos expiatorios. "Violencia", en particular el capítulo "El cólera y los jóvenes", es la más autobiográfica del libro ya que, a diferencia de los otros brotes epidémicos analizados en el libro, el autor de Hijos de la peste fue testigo experiencial de la epidemia del cólera de 1991 cuando era estudi- ante en la Universidad de San Marcos. Como señala Velázquez, "[I]a epidemia del cólera en 1991 fue parte de una tormenta perfecta, porque concurrió con una feroz crisis económica, una acelerada descomposición social y un conflicto armado interno en su fase más violenta". Además, "[a] diferencia de la COVID-19, que corona trágicamente años de crecimiento económico; el cólera de 1991 ocurrió poco después de la catástrofe económica de la hiperinflación y cuando la pobreza alcanzaba al 57.4 \% de la población en el Perú".

La última sección, "Humor", compuesta por los capítulos "La carcajada y la sonrisa", "El miedo risueño", "Dibujar la muerte", "El talento mortal de los políticos y la risa de los médicos", "La higiene y el hedor. La fantasía de la desinfección" y "Las huellas de la enfermedad". Si bien Hijos de la peste se caracteriza por las frecuentes referencias a la literatura, pintura y caricatura, "Humor" enfatiza estas obras literarias, artísticas y populares como respuestas ante la epidemia y la represión que usualmente le acompaña: "En estos tiempos de pandemia, la ciencia médica y la estadística reinan; se ha instaurado un nuevo orden en el que la biopolítica y el estado de excepción emergen en todo su esplendor para administrar la vida, la libertad y el deseo. La imaginación nos permite ver con otros ojos esta experiencia insólita: reír contra la muerte y sonreír ante nuestras desventuras".

En el "Epílogo", Velázquez concluye su brillante estudio regresando a la pandemia del COVID-19 que estamos sufriendo. Pasa revista a las reacciones tanto del Estado como de la sociedad civil ante la pandemia. De hecho, concluye criticando las acciones del Estado -entonces el gobierno de Vizcarra- que palidecen ante lo logrado por la Iglesia: "En su tarea de enfrentar al virus, el gobierno no articuló a otros sectores, no pudo realizar un rastreo de contactos y terminó culpabilizando a la población. En cambio, el programa pastoral de la Iglesia Católica involucró a la empresa, la academia, la sociedad civil, y promovió formas de organización solidaria y comunitaria".

Empecé este breve resumen de Hijos de la peste señalando el necesario desfase entre el estudio y el objeto estudiado. Y, como hemos visto, Velázquez pasa revista a la historia de las pandemias y de las repuestas médicas, políticas e ideológicas ante estas desde fines del incario hasta el presente. Pero el búho de Minerva mira al presente antes de volar. $Y$ es desde la perspectiva del presente que se puede evaluar al pasado y que el pasado puede ayudar a entender al presente. Por eso, Hijos de la peste tiene una inquietante actualidad. Las epidemias de cólera y de peste bubónica que detalla sirven como espejos para la pandemia en que vivimos y que de hecho el libro también estudia. El pasado nos ayuda a comprender el presente y, como señala Velázquez en este magnífico estudio, nuestro casi seguro futuro.

\section{Juan De Castro}

The New School Eugene Lang College of Liberal Arts, Nueva York, Estados Unidos

Contacto decastrj@newschool.edu

https://orcid.org/0000-0002-8487-5458 